\title{
ANTIBIOTICS RESISTANCE PROFILE OF BACTERIAL STRAINS PRODUCED OF BIOFILM ISOLATED FROM PATIENTS IN AL- DIWANIYA CITY, IRAQ
}

\author{
Abeer Hamoodi Jabbar \\ Department of Biology \\ University of AL- Qadisiyah, \\ AL-Diwanyia Province, Iraq
}

\author{
Muqdad Irhaeem Kadhim \\ Department of Chemistry \\ University of AL- Qadisiyah, \\ AL-Diwanyia Province, Iraq
}

\author{
Mustafa Hamoodi Jabbar \\ Department of Environmental \\ University of AL- Qadisiyah, \\ AL-Diwanyia Province, Iraq
}

\author{
Israa Saleh Obayes \\ College of Law \\ University of AL- Qadisiyah, \\ AL-Diwanyia Province, Iraq
}

\author{
Hussein H. Al-Shafai \\ Department of Biology \\ University of AL- Qadisiyah, \\ AL-Diwanyia Province, Iraq
}

Abstract-Majority of the microorganisms develop different types of survival mechanisms such as growth regulation, heterogeneity in population, proteolytic systems etc. to adapt to stress conditions. Pathogenic microorganisms acquire the ability to sustain various host immunological responses, The study included collection of about 150 clinical samples from a patients and included samples (Urine, fecal and blood). And for both gender and of all, The necessary examinations and tests were performed for the bacterial isolates. The results were as follows presence of five bacterial genera and in percentage Pseudomonas aeruginosa 12 isolates (40\%), Escherichia coli 10 isolates (33.3\%), Staphylococcus 5 isolates (16.6\%), 1 isolate (3.33\%). bacillus isolates (6.6\%)2 and then Proteus mirabilis

Also using the Field Emission Scanning Electron Microscopy (FE-SEM) to detection of the biofilm, The isolates was tested to 12 antibiotic by kirby bauer method and the results was presence of high ratio of resistant. Where the bacterial strains showed high resistance against (Amoxicillin, Amikacin, Cefotaxime, Ciprofloxacin, Gentamicin, Nalidixic acid, Ceftazidime, Cefoxitin) while The remaining antibiotics show middle and low resistance.

Key words - Biofilm; Antibiotics resistance, isolation of bacteria

\section{INTRODUCTION}

Biofilms defined as the well-organized cooperating communities of surface-associated microorganisms enclosed in extracellular matrix produce by themselves. It is a trait of microorganisms (bacteria) (Hall et al ., (2004) ; Stewart et al
., (2008). Biofilms are heterogeneoeus congregation for surface associated microorganisms encapsulated within a self-produced polymermatrix consisting of polysaccharide, protein and DNA. Several factors such as bacterial defenses mechanisms, suitable areas for colonization, the community cooperation related benefits and extraordinary mode of growth in their habitat accelerate biofilms formation (Jefferson, 2004). Bacteriae such as $S$. aureus $P$. aeruginosa, Acinetobacter baumanniiand other clinically important microorganismses that thrive on medical devices form biofilmes that confer them from resistance and tolerance to antibiocides as compared to their planktonice forms. About $80 \%$ of the pathogenic bacteria are associated with medical device related infections such as ortho dental prosthetics, contact lenses, cardiovascular valves, urinary catheters, pacemakersand breast implants (Scott, 2009). Bacteria residing in the biofilm are protected by the shelter and homeostasis as the EPS are produced having protein, nucleic acid, carbohydrate and other substances. It plays a key role in structure forming and functioning of biofilm communities in diverse environments Antimicrobial agents and biofilm microbial community combat for dominancy where diffusion of molecules determine the success. Biofilm has the ability to develop a barrier of EPS against diffusion molecules of the antimicrobial agents.

$P$. aeruginosa forms biofilms on wet surfaces and in hospital environments such as sinks, humidifiers, and respiratory therapy equipment [Ruiz]. Therefore, the organism can be often isolated from a variety of sources in hospital environments, including respi-ratory therapy equipments, antiseptics, soaps, sinks, mops, medicines, and physiotherapy-hydrotherapy pools and feces of patients (Shehabi et al., (2005). Microbial resistance to antimicrobial agents is due to either (i) 


\section{International Journal of Engineering Applied Sciences and Technology, 2019 Vol. 4, Issue 8, ISSN No. 2455-2143, Pages 295-299 \\ Published Online December 2019 in IJEAST (http://www.ijeast.com)}

intrinsic properties (natural phenotypic traits) or (ii) the acquisition of resistance genes through mobile genetic elements, such as plasmids and transposons, or the mutation of indigenous genes (European Food Safety Authority, (2012).

\section{MATERIALS AND METHODS}

The study was conducted over a period of six months, A total of 150 samples were collected from different ages of clinical patients who were visited different hospitals in Al-Diwaniyah city, Iraq, The ages of patients ranged from few days to 60 years old.

A. Isolation and identification The specimens that include (blood, fecal and urine) were transported immediately to the lab and inoculated on MaConckey and blood agar, and incubated aerobically at $37{ }^{\circ} \mathrm{C}$ for $24 \mathrm{~h}$. Non-lactose fermenting pale colonies from MaConckey and large flat dark greenish colonies from blood agar (after sub-culturing on nutrient agar) were tested for conventional biochemical tests: oxidase test, catalase, citrate utilization, and oxidative fermentation. The isolates were further sub-cultured on to two nutrient agar plates and incubated separately. Based on colony morphology, gram stain, oxidase test, urease test, Simon-citrates test.

$B$. Diagnosis of bacteria: bacteria and colonies are diagnosed Developing depending on the phenotypic characteristics which include Forms of colony, color, surface of the colony and its structure Smell, transparency, and the pattern of hemolysis on medium Blood and lactose fermentation on medium agar macConkey (Winn et al., (2006). It was also diagnosed microscopically, as samples were examined by taking Smear from the bacterial colonies growing on the media The implant was attached and stained with Gram stain for observation Forms and arrangement of bacterial cells and their interaction with dye, Biochemical tests were also performed (Brown, 2007).

C. direct detection of Biofilms via Field Emission Scanning Electron Microscopy (FE-SEM( The biofilm formation ability of isolates were examined by FE-SEM. The surfaces were prepared with some modifications as described previously by Jahid et al., (2013). The surfaces were fixed at room temperature for $4 \mathrm{~h}$ with $2.5 \%$ glutaraldehyde. The surfaces were then serially treated with ethanol $(50 \%$ for $15 \mathrm{~min}, 60 \%$ for $15 \mathrm{~min}, 70 \%$ for $15 \mathrm{~min}, 80 \%$ for $15 \mathrm{~min}, 90 \%$ for $15 \mathrm{~min}$, and twice with $100 \%$ for 15 min each time) and successively dehydrated by soaking in $33,50,66$, and $100 \%$ hexamethyldisilazane in ethanol for $15 \mathrm{~min}$ each time. The dehydrated surfaces were sputter coated with platinum and visualized by FE-SEM (Hitachi/Baltec, S-4700). In this study. $D$. Indirect detection of biofilm by Plate count Quantitative Culture plating to determine the number of colony forming units (CFU). (González et al ., 2018). Quantitative Cell counts from biofilms are calculated.

\section{$E$. Sensitivity test}

kirby bauer method: The drug sensitivity of bacterial isolates was tested in a manner Tablets depending on that include transfer To bacterial isolates 4 colonies of bacteria-2 A test tube contains $5 \mathrm{ml}$ of soy tryptone broth Nourished and incubated at $37^{\circ} \mathrm{C}$ for 8 hours. Tempered Growth using physiological salt solution, completed Comparing Growth in Tube with Macfarland Tube (0.5) Standard, cotton swab dipped in Trypton broth Cultivated soy, squeeze out the sides Interior of the tube, bacteria spread on the Muller Hinton medium Steel by way of planning more than once And in different directions for the purpose of making sure the bacteria are spread Equally tested their sensitivity, and the dishes were left 15 minutes At room temperature to ensure absorption Moisture, antibiotic tablets were placed To the center of the other disc, the dishes were incubated at $37^{\circ} \mathrm{C}$ For 18 hours for all types of antibiotics, then measured Inhibition diameters using Vernia and were compared with values Standard mentioned in $\mathbf{3}$ table.

\section{RESULTS and DISCUSSION}

A general definition of antimicrobial resistance is the ability of an organism to resist the action of an antimicrobial agent to which it was previously susceptible. Where some of this bacterial genera considered as Nosocomial infections caused by antibiotic resistant $P$. aeruginosa, E. coli, Staphylococcus sp have emerged as major concern in clinical care settings as the increasing development of MDR strains (i.e. resistance to at least three antibiotics) (Juan et al., (2005). Samples were isolated from the patients in Al-Diwaniyah city/Iraq. Blood, stool and urine isolates were randomly collected from infected patients and from all ages of (children to elderly) and for both sexes who showed symptoms of bacterium infection where the current study about 150 samples and the positive samples are $30(20 \%)$ isolates, also this microorganisms can be present in soil (Kadhim et al ., 2019) Table .1.

Table 1: bacterial isolation Ratio in patients

\begin{tabular}{|l|l||l|l|}
\hline Result & $\begin{array}{l}\text { Total } \\
\text { samples }\end{array}$ & No. & Percentage\% \\
\hline \hline $\begin{array}{l}\text { Positive } \\
\text { samples }\end{array}$ & 150 & 30 & $20 \%$ \\
\hline $\begin{array}{l}\text { Negative } \\
\text { samples }\end{array}$ & & 120 & $80 \%$ \\
\hline
\end{tabular}

and then isolates were identified by examination of morphology of colony on each culture media. isolates were differentiated to 30 bacterial strains include (Pseudomonas aeruginosa 12 (40\%) and Escherichia coli 10(33.3\%) and Staphylococcus $5(16.6 \%)$ and Proteus mirabilis $2(6.6 \%)$ and bacillus $1(3.33 \%)$. 


\section{International Journal of Engineering Applied Sciences and Technology, 2019 \\ Vol. 4, Issue 8, ISSN No. 2455-2143, Pages 295-299 \\ Published Online December 2019 in IJEAST (http://www.ijeast.com)}

Table 2: bacterial strains produced of biofilm and Gram stain

\begin{tabular}{|l|l|l|}
\hline Genus & Gram stain & NO.isolates \\
\hline $\begin{array}{l}\text { Pseudomonas } \\
\text { aeruginosa }\end{array}$ & Gram negative & $\mathbf{3 0 \% 1 2 (}$ \\
\hline Escherichia coli & Gram negative & $10(33.3 \%)$ \\
\hline Staphylococcus & Gram positive & $5(16.6 \%)$ \\
\hline Proteus mirabilis & Gram negative & $2(6.6 \%)$ \\
\hline
\end{tabular}

\begin{tabular}{|l|l|l|}
\hline bacillus & Gram positive & $1(3.33 \%)$ \\
\hline total & & $30(99.9 \%)$ \\
\hline
\end{tabular}

The results showed the high resistance of bacterial strains towards antibiotic in amoxicillin and Amikacin, Cefotaxime, Gentamicin, Nalidixic acid, Ceftazidime, Cefoxitin ranging from (70\%-99.4\%). where as the ampicillin and azithromycin , ciprofloxacin, chloramphenicol, tetracycline ranging from (28\%-70\%) show the low or mediated resistant .

Table 3. the Antibiotic resistance profile of bacterial strains produced biofilms based on inhibition zone diameter (mm).

\begin{tabular}{|c|c|c|c|c|c|}
\hline Antibiotic & $\begin{array}{c}\text { Pseudomonas } \\
\text { aeruginos }\end{array}$ & $\begin{array}{c}\text { Escherichia } \\
\text { coli }\end{array}$ & Staphylococcus & $\begin{array}{c}\text { Proteus } \\
\text { mirabilis }\end{array}$ & bacillus \\
\hline Amoxicillin & 70 & 82.1 & 85 & 70 & 91.1 \\
\hline Ampicillin & 28 & 40 & 30.4 & 31.3 & 33.9 \\
\hline Amikacin & 88 & 89 & 90 & 90.2 & 92 \\
\hline Cefotaxime & 89.5 & 89 & 84 & 81 & 93 \\
\hline Azithromycin & 60 & 79 & 66 & 68.2 & 70 \\
\hline Ciprofloxacin & 70.1 & 69.3 & 67.3 & 77.3 & 80.5 \\
\hline Choramphenico & 50 & 40 & 44 & 53 & 34 \\
\hline Tetracycline & 70 & 60 & 74 & 58 & 40 \\
\hline Gentamicin & 90 & 87 & 54.2 & 77.9 & 85 \\
\hline Nalidixic acid & 81 & 92 & 85 & 75 & 90 \\
\hline Ceftazidime & 86 & 90 & 89 & 91 & 77 \\
\hline Cefoxitin & 98 & 99.4 & 90 & 91.5 & 97.7 \\
\hline
\end{tabular}

The described tolerance mechanisms, all contribute to the persistence of biofilms, which provide a fertile ground for the emergence of antibiotic-resistant mutants. In planktonic cultures, it has been reported that tolerance precedes the occurrence of resistance (Levin-Reisman et al., (2017).

In study by Yayan et al ., (2015) similar resistance pattern was seen with ciprofloxacin $(35.2 \%$ vs. $24.0 \% ; 70.4 \%$ vs. $61.5 \%)$, ceftazidime $(15.9 \%$ vs. $30.9 ; 33.3 \%$ vs. $61.5 \%)$, gentamicin ( $26.4 \%$ vs. $18.2 \%$; $44.4 \%$ vs. $21.4 \%$ ), and meropenem $(20.2 \%$ vs. $20.3 \% ; 42.3 \%$ vs. $50.0 \%$ ). An elevated resistance of $P$. aeruginosa and MDR P. aeruginosa was found for amikacin $(10.2 \%$ vs. $9.1 \% ; 27.3 \%$ vs. $9.1 \%)$. While in other study by Telling et al ., (2018) showed the resistance ratio of isolates was of Ceftazidime, Gentamicin ,Ciprofloxacin, Amikacin $(26.1 \%, 19.6 \%, 46.7 \%, 7.6 \%)$ and this no identicle to the present study .

In study by Pormohammad, et al (2019) showed that $E$. coli strains isolated have the lowest and highest resistance rates were for tetracycline $(60 \%$,),resistance to, cefotaxime, and ceftazidime was $1 \%(95 \%-14.5 \%)$ and for nalidixic acid $53 \%$. and this identical to the present study, while in other study by Naiyf et al ., (2019) showed that More than 50\% of the $E$. coli isolates obtained from wound infections were resistant to, ampicillin, ciprofloxacin, and tetracycline;

In Germany study by Fiedler et al ., (2019) showed that Bacillus strains showed resistance against the $\beta$-lactam antibiotics such as cefotaxim $(100 \%)$, as well as amoxicillin and ampicillin (99.3\%). Most strains were susceptible to ciprofloxacin $(99.3 \%)$, chloramphenicol (98.6\%), amikacin $(98.0 \%)$, imipenem $(93.9 \%)$, gentamicin $(88.4 \%)$, tetracycline $(76.2 \%)$ and this no identical to the current study.

Study by Gulcan Sahal Isil Seyis Bilkay, (2017) showed that the Antibiotic sensitivity testing of $P$. mirabilis strains against 15 different antibiotics revealed that all 15 strains tested were sensitive to third generation cephalosporins, also were resistant to ampicillin and ceftazidime among $\beta$-lactam antibiotics, and gentamicin among aminoglycoside antibiotics. P. mirabilis strains were the only strains showing resistance to ciprofloxacin 


\section{International Journal of Engineering Applied Sciences and Technology, 2019 \\ Vol. 4, Issue 8, ISSN No. 2455-2143, Pages 295-299 \\ Published Online December 2019 in IJEAST (http://www.ijeast.com)}

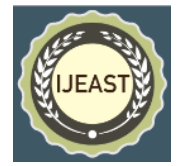

.in Algeria study by Achek, et al., (2018) The antimicrobial resistance rates were higher in clinical isolates. The resistance rates of $S$. aureus to tetracycline were $48.7 \%$ Staphylococcus aureus showed considerable resistance (52.4\%) to gentamycin. While other study by Oladipo et al ., (2019) was solates were resistant to amoxycillin $(91.7 \%)$, ciprofloxacin $(84.0 \%)$, azithromycin $(78.0 \%)$, ceftazidime $(76.0 \%)$, gentamycin (75.0\%), and study by Wang et al ., (2019) resistant of tetracycline was common S. aureus about (31.5\%). Resistance gentamicin $(9.0 \%)$, and this results was no identical to the present study.

The Antibiotics resistance implies mutations in resistance genetics determinants lead to increase antibiotic minimal inhibitory concentrations for bacterial cells disrupted from biofilm and it is accepted as a side-effect of prolonged maintenance antibiotic therapy. In contrast to the planktonic, fast-dividing cells that are traditionally used to study antibiotic resistance development in shaking cultures, biofilm-grown bacteria encounter gradients of nutrients and oxygen which lead to a heterogeneous bacterial population including slow-growing or non-dividing cells (Stewart, 2015; Stewart et al., 2016).

\section{CONCLUSION}

The study included isolation of bacteria producing Biofilms, as these bacteria are distinguished by their multiple resistance to antibiotics, and this may be due to their possession of other mechanisms that lead to this resistance, as these Biofilms are not affected by sterilization and disinfection, and therefore the presence of resistant strains and the difficulty of accepting these bacteria for treatment.

\section{ACKNOWLEDGEMENT}

I extend my thanks and appreciation to my colleagues in this research and to further scientific progress, Their keen interest and constant encouragement gave me the confidence to complete my work. I wish to extend my sincere thanks for their excellent guidance and suggestions for the successful completion of my seminar work.

\section{REFERENCES}

1-Jahid, I. K., Lee, N. Y., Kim, A., and Ha, S. D. (2013). Influence of glucose concentrations on biofilm formation, motility, exoprotease production, and quorum sensing in Aeromonas hydrophila.J. Food Prot. 76, 239-247. doi: 10.4315/0362-028X.JFP-12-321

2 -González-R , F.; Ripolles-A , C.; Fontecha-U , F.; Ríos-C , A.G.; Rodríguez-J , J.J.(2018). Biofilms in the Spotlight: Detection, Quantification, and Removal Methods. Compr. Rev. Food Sci. Food Saf. 2018, 17, 1261-1276.

3-Hall-S L, Costerton JW, Stoodley P( 2004). Bacterial biofilms: from the natural environment to infectious diseases Nature. Reviews Microbiology Journal. 2004; 2:95-108.
4-Stewart PS, Franklin MJ.(2008). Physiological heterogeneity in biofilms. Nature Reviews Microbiology Journal. 2008; 6:199-210. Jefferson, K.K., 2004. What drives bacteria to produce a biofilm? FEMS Microbiol. Lett. 236 (2), 163-173.

5-Scott, R.D.I., 2009. The Direct Medical Costs of HealthcareAssociated Infections in U.S. Hospitals and the Beneftis of Prevention. Division of Healthcare Quality Promotion National Center for Preparedness, Detection and Control of Infectious Diseases.

6-Acco M, Ferreira FS, Henriques JAP, Tondo EC (2003) Identification of multiple stains of Staphylococcus aureus colonizing nasal mucosa of food handlers. Food Microbiology 20: 489493 .

7-Oyeleke, S B. and Manga, B. S,(2008). Essentials Of Laboratory Practicals in Microbiology 2008. P. 63-65.

8-Levin-R , I., Ronin, I., Gefen, O., Braniss, I., Shoresh, N., and Balaban, N. Q. (2017). Antibiotic tolerance facilitates the evolution of resistance. Science 355, 826-830. doi: 10.1126/science.aaj2191.

9-Stewart, P. S., Franklin, M. J., Williamson, K. S., Folsom, J. P., Boegli, L., and James, G. A. (2015). Contribution of stress responses to antibiotic tolerance in Pseudomonas aeruginosa biofilms. Antimicrob. Agents Chemother. 59, 3838-3847. doi: 10.1128/AAC.00433-15.

10-Stewart, P. S., Zhang, T., Xu, R., Pitts, B., Walters, M. C., Roe, F., et al. (2016). Reaction-diffusion theory explains hypoxia and heterogeneous growth within microbial biofilms associated with chronic infections. NPJ. Biofilms. Microbiomes. 2:16012. doi: 10.1038/npjbiofilms.2016.12.

11- Pormohammad A , Mohammad J N , and Taher A , (2019). Prevalence of antibiotic resistance in Escherichia coli strains simultaneously isolated from humans, animals, food, and the environment: a systematic review and metaanalysis, Infect Drug Resist. 2019; 12: 1181-1197.

12- Winn, J. W.; Allen, S.; Janda, W.; Koneman, E.; Procop, G.; Schreckenberger, P. and Woods, G. (2006). Koneman's Color Atlas and Textbook of Diagnostic Microbiology, $6^{\text {th }} \quad$ ed., Lippincott-raven Publishers Philadelphia, PP: 239-270. USA.

13- Naiyf S.A ,Jamal M .Khaled A K , Ahmed S.A ,Anwar H.Sh, Sami A.A Taghreed N. Al M A.A, Muhammed R. Shehu (2019). Prevalence of Escherichia coli strains resistance to antibiotics in wound infections and raw milk, Saudi Journal of Biological Sciences Volume 26, Issue 7, November 2019, Pages 1557-1562.

14- Yayan J, Beniam Gh, Kurt R (2015). Antibiotic Resistance of Pseudomonas aeruginosa in Pneumonia at a Single University Hospital Center in Germany over a 10-Year Period, Published: October 2, 2015https://doi.org/10.1371/journal.pone.0139836.

15- Telling K, Mailis L, Age B , Maido R, Veljo K, Matti M , Tanel $\mathbf{T} \&$ Irja $\mathbf{L}$ (2018). Multidrug resistant Pseudomonas aeruginosa in Estonian hospitals, Research article Published: 11 October 2018. 


\section{International Journal of Engineering Applied Sciences and Technology, 2019 \\ Vol. 4, Issue 8, ISSN No. 2455-2143, Pages 295-299 \\ Published Online December 2019 in IJEAST (http://www.ijeast.com)}

16- Fiedler G , Carmen S , Etinosa O. I , , Jan K , Erik B , Biserka B , Dominic A. S , Gyu-Sung C , Melanie H and Charles M. A. P. Franz(2019). Antibiotics resistance and toxin profiles of Bacillus cereus-group isolates from fresh vegetables from German retail markets, Fiedler et al. BMC Microbiology (2019) 19:250.

17- Gulcan S I and Seyis B , (2017) . Multidrug resistance by biofilm-forming clinical strains of Proteus mirabilis, DOI: https://doi.org/10.5372/1905-7415.0904.424.

18-Brown, A $\quad$ A (2007). $\quad$ Bensons general microbiology. McGraw -Hill Co.INC. USA . P:102 263, Microbiological application laboratory.

manual in

19-Achek R , ,Helmut H , Zafer C , Ibrahim N , Taha M H, Heinrich N, and Hosny El-A (2018). Emerging of antimicrobial resistance in staphylococci isolated from clinical and food samples in Algeria, Published online 2018 Sep 12. doi: 10.1186/s13104-018-3762-2.

20-Oladipo Adegboyega O.; Oluwatosin G. Ol ; Cornelius C. Bezuidenhout (2019). Multi-drug resistance traits of methicillin-resistant Staphylococcus aureus and other Staphylococcal species from clinical and environmental $\begin{array}{llllll}\text { sources ,J Water Health (2019) } 17 & \text { (6): 930-943 }\end{array}$ https://doi.org/10.2166/wh.2019.177.

20-Wang Yu-Ting, Yu-Tzu Lina, Tsai-Wen Wana, DerYuan Wangb, Hsu-Yang Linc, Che-Yang Linb, Yu-Chih Chenb, Lee-Jene Teng (2019). . Distribution of antibiotic resistance genes among Staphylococcus species isolated from ready-to-eat foods , October 2019Volume 27, Issue 4, Pages 841-848.

21-Ruiz L, Domínguez MA, Ruiz N, Viñas M. Relationship between clinical and environmental isolates of Pseudomonas aeruginosa in a hospital setting. Arch Med Res 2004; 35:251257.5.

22-- Kadhim M , I ( 2015).Synthesis and biological evaluations of new phenothiazine derivatives journal of alqadisiyah for pure science(quarterly).

23-Juan C., Macia M.D., Gutierrez O., Vidal C., Perez J.L., Oliver A. Molecular mechanisms of beta-lactam resistance mediated by AmpC hyper production in Pseudomonas aeruginosa clinical strains. Antimicrob Agents Chemother. 2005;49(11):4733-

4738.

24-European Food Safety Authority 2012. Scientific opinion on guidance on the assessment of bacterial susceptibility to antimicrobials of human and veterinary importance. EFSA J. 10: 2740 .

25- Kadhim M , I, . Jabbar M , H . Mohammed W , J . AlShamkhee Z A K . Obayes I, S . Jabbar A H.(2019). Isolation and Identification of different microorganisms in the soil in the Diwaniyah city in Iraq , Pramana Research Journal Volume 9, Issue 12, 2019 ISSN NO: 2249-2976.
26- Kadhim M , I( 2019). Endocrine disrupting Bisphenol A detection in different water samples in Iraq Journal of Physics: Conf. Series 1294 (2019) 052045.

27-Shehabi AA, Masoud H, Balkam Maslamani FA. Common Antimicrobial Resistance Pattern, Biotypes and Serotypes Found among Pseudomonas aeruginosa Isolates from Patient's Stools and Drinking Water Sources in Jordan. J Chemother 2005; 17 (2): 179 -183. 